\title{
The Human Right to a Good Environment - The sword in the stone
}

\author{
STEVE TURNER*
}

\begin{abstract}
In 1994, the Secretary General of the United Nations said that, "without protection of the environment, the basis of human survival will be eroded." Time has shown that the principles of "sustainable development" alone will not be sufficient to protect the environment. Time has shown that the interest that present and future generations have in the environment need to be rooted in positive law. The argument is that the human right to a good environment provides a cost effective, forward thinking and practical method of dealing with environmental problems. The first step in its introduction would be for the right to be recognised formally on an international level. The second step would be the introduction of appropriate legal mechanisms and regulations that govern decision making on a day to day basis.
\end{abstract}

Keywords: environment, human rights, sustainable development

\section{Introduction}

This article examines the "Human Right to a Good Environment" as a practical method of protecting the environment on a domestic and international basis. It aims to show that rather than being a vague unworkable concept, it can be used as a highly practical tool, not only by states, but by businesses, NGOs and individuals alike.

It does this by first setting out the draft human right to a good environment. It then goes on to examine existing international and domestic law, ascertaining to what extent rights to a good environment already exist. Therefore it examines international environmental law treaties, human rights law, the approach of individual states to the issue and the approach of the international courts. It then goes on to look at the reasons or arguments that are integral to the debate as to whether or not such a right should be instituted. This is done by discussing the linkages between human rights and the environment, by looking at scientific evidence, by examining contemporary institutional pronouncements and through the analysis of the deficits in the current systems of environmental protection on both a national and international level. The next stage is to analyse the discourse that has surrounded environmental rights and to put the arguments into perspective.

The final stage, which flows from this, is to show how such a right can be entirely workable on a practical and financial level taking into account the needs of business, the requirements of industry, the problem of poverty and the rights of future generations.

* Steve Turner is a legal adviser and also a $\mathrm{PhD}$ candidate at London University. The author would like to thank Professor Malgosia Fitzmaurice for help with previous drafts. 


\section{The Draft Human Right to a Good Environment}

Any decision by a person, group of people, organisation or government that brings about or could bring about degradation of the environment, is contrary to the human right to a good environment and as such is fundamentally unlawful. It is a human right to be able to challenge such decisions throughout the process of decision making and in courts of law and tribunals. Environmental degradation can be rendered lawful when brought about to satisfy other basic human rights and where other less environmentally degrading alternatives are not viable. In the event that such decisions are sanctioned on the grounds that it is necessary to cause environmental degradation to satisfy other basic human rights, the degradation must be tied to an equitable form of compensation that in at least equal measure, benefits the environment of the community or the area of land, air, sea, ecosystem or water that is suffering or would suffer that degradation or risk of degradation. ${ }^{1}$

\section{Is there currently a human right to a good environment?}

\subsection{International Environmental Law}

The link between human rights and the environment was made at the United Nations Conference on the Human Environment in Stockholm in 1972. Its declaration in Principle 1 states that, "[m]an has the fundamental right to freedom, equality and adequate conditions of life in an environment of a quality that permits a life of dignity and well being, and he bears a solemn responsibility to protect and improve the environment for present and future generations." ${ }^{2}$ In spite of this pronouncement, many were disappointed that the language used did not state categorically that a new environmental right was being declared.

What was clear however was a desire in the drafting process to establish in Principle 1 , the relationship between man and the environment and to attach to this, certain rights and responsibilities along with a concomitant responsibility to future generations. However on looking at Principle 2, it is noticed that it refers not to rights but to an affirmation of the need to address existing problems of the environment and to the effect that these will have on present and future generations. It states that, "[ $t]$ he natural resources of the earth, including the air, water, land, flora and fauna and especially representative samples of natural ecosystems, must be safeguarded for the benefit of present and future generations through careful planning or management, as appropriate." 3

Although these principles may have been acknowledged on an international level, they were not elevated during the following years to the status of customary international law. This was in spite of certain declarations which appeared to support the concept of new environmental rights by state leaders ${ }^{4}$ and the General Assembly of

\footnotetext{
1 The Human Right to a Good Environment (draft by the author).

2 Declaration on the Human Environment, Principle 1, Report of the United Nations Conference on the Human Environment (New York 1973) [hereinafter UNCHE], U.N. Doc. A/Conf. 48/14/Rev. 1 (1972), adopted in G.A. Res. 2997. U.N. GAOR, 27th Sess., Supp. No. 30, at 43, U.N. Doc. A/8901 (1972).

3 Ibid., Principle 2.

${ }^{4}$ Declaration of the Hague on the Environment, 11th March 1989, 28 I.L.M., 1308, (1989).
} 
the United Nations. ${ }^{5}$ It would not be until the United Nations Conference on Environment and Development in Rio de Janeiro that the progression of an environmental right could really be assessed. Principle 1 of the Rio declaration of 1992 stated that, "[h]uman beings are at the centre of concerns for sustainable development. They are entitled to a healthy and productive life in harmony with nature."

This shift away from the emphasis on a "fundamental right" and "protecting and improving the environment" and the move towards human beings being at the "centre of concerns for sustainable development" caused considerable debate. ${ }^{7}$ It was perhaps indicative of the advent of the concept of "sustainable development" which became the key phrase that would come to dominate environmental discussions from that time onward and an indication of the way that large scale compromises had to be made at Rio to engage widespread international support. Therefore, although some of the principles from UNCHE and UNCED have become recognised as norms of customary international law, ${ }^{8}$ they are on the whole, non binding agreements that are regarded as "soft law".

One of the major stumbling blocks facing the concept of a human right to a good environment is that of state sovereignty over natural resources. The doctrine of sovereignty pervades international law and therefore is one of the major precepts that governs international environmental law treaties. ${ }^{9}$ The principle of permanent sovereignty over natural resources has been recognised by numerous resolutions of the General Assembly of the United Nations. ${ }^{10}$ This principle means that a state, subject to exceptions, ${ }^{11}$ is entitled to utilise its own natural resources in pursuance of its own policies.

This doctrine, for many states, justifies the manner in which they treat the environment. ${ }^{12}$ Although increasingly states have entered into international treaties whereby

${ }^{5}$ G.A. Res 45/94, U.N. GAOR, 45th Sess., Supp. No. 49A, at 178, U.N. Doc. (A/45/749) (1990).

${ }^{6}$ United Nations Conference on Environment and Development [hereinafter UNCED], 31 I.L.M. 814. 876 (1992); or U.N. Doc. A/Conf. 151/5/Rev. 1 (1992).

7 See e.g. Shelton, "What happened in Rio to Human Rights?" 3 Yearbook of International Environmental Law 75 (1992).

${ }^{8}$ For example Principle 21 of UNCHE is widely regarded as reflecting customary international law. See Philippe Sands, Principles of International Environmental Law, 146 (Cambridge University Press, 2003).

9 E.g. Principle 21 of UNCHE (1972); Principle 2 of UNCED (1992) and the Preamble of the Convention on Biological Diversity (1992).

${ }^{10}$ E.g. Resolution 1803 (XVII) 14 December 1962; Resolution 3201 i.e. Declaration on the Establishment of a New International Economic Order of 1 May 1974 and Resolution 3281 i.e. The Charter of Economic Rights and Duties of States 12 December 1974.

11 E.g. Principle 21 of UNCHE (1972) asserts the customary international law principle of "sic utere tuo ut alienum non laedas". In other words, whenever a state makes use of its own territory in an arbitrary fashion and thereby causes unjustifiable loss or damage in another state, such action should be deemed to be contrary to international law.

12 The Amazon Declaration (1989) which concerns itself with the conservation of the environment and respecting the rights of indigenous peoples but recognises this against the affirmation that each country has the sovereign rights to freely manage its natural resources. Discussion is found in Nico Schrijver, Sovereignty over Natural Resources - Balancing Rights and Duties, 328 (Cambridge University Press, 1997); see also Surya P. Subedi, "Incorporation of the Principle of Sustainable Development into the Development Policies of the Asian Countries”, 32(2) Environmental Policy and Law 85 (2002). 
they have recognised obligations to protect the environment and it is possible to argue that this has affected the concept of permanent sovereignty over natural resources, the basic principle has been consistently reaffirmed. ${ }^{13}$ As Schrijver says, "[s]tates have the right to pursue freely their own economic and environmental policies, including conservation and utilization of their natural wealth and the free disposal of their natural resources, on the other hand, obligations and responsibilities have emerged which confine States' freedom of action." ${ }^{14}$ However Schrijver recognises that international environmental law, "is a body of law not yet endowed with sophisticated monitoring and control mechanisms and an authoritative and binding method of settling disputes." ${ }^{15}$ It is therefore clear that the soft law obligations under UNCED for example are weak in comparison to the control that each state has over its own natural resources.

The recognition of a human right to a good environment would have the effect of providing a counter balance to this principle. At present, the doctrine of sovereignty has a restraining effect on the proper development of the human right to a good environment. It is for this reason that this article argues inter alia that it should be recognised at both a national and an international level that the principle of permanent sovereignty over natural resources, should be subject to the human right to a good environment. This is discussed later in greater detail.

\subsection{Substantive and procedural rights}

"Substantive" rights and "procedural" rights have had differing degrees of success in establishing themselves in the arena of environmental protection. This is because whereas a "substantive" environmental right would entitle the holder to a specific quality of environment, a "procedural" environmental right would only entitle the holder to participate in processes of decision making relating to environmental issues. Procedural rights are those that allow individuals the right to information, participation and the right to challenge decisions that affect their environment. In terms of the environment these concepts were summed up in Principle 10 of the Rio Declaration. ${ }^{16}$

Procedural rights have received widespread support in many of the most recent international and regional environmental law treaties. ${ }^{17}$ It can be argued that the process of involving citizens in decision making means that better decisions are made as all the relevant factors are taken into account. It can also be argued however that the reluc-

\footnotetext{
13 For a historical breakdown see Nico Schrijver, supra note 12.

${ }^{14}$ Nico Schrijver, supra note 12 at 252.

15 Nico Schrijver, supra note 12 at 235.

15 For a historical breakdown see Nico Schrijver, supra note 12.

16 Principle 10 of UNCED supra note 6.

17 See for example the Protocol to the 1979 Convention on Long-Range Transboundary Air Pollution Concerning the Control of Emissions of Volatile Organic Compounds or Their Transboundary Fluxes (Geneva, November 18, 1991), Article 2 (3)(a)(4); Article 14(1) of the Convention on Biological Diversity (1992); Article 14(i) of the Climate Change Convention (1992); The Kyoto Protocol to the United Nations Framework Convention on Climate Change (December 10, 1997), Article 6(3); the Convention on EIA in a Transboundary Context (1991), Articles 2(6) and 3(8). N.B. There have been limited exceptions to this such as The Convention on Non-Navigable Uses of International Watercourses (1997).
} 
tance of states to commit themselves to a substantive environmental right, means that regardless of any procedural rights, there is no guarantee that the environment will be protected. In spite of their drawbacks, many writers on the subject applaud the development of procedural rights as a realistic way of bringing environmental interests to the fore of decision-making processes. ${ }^{18}$

For example, Article 6 of the 1993 North American Agreement on Environmental Cooperation states that persons with a "legally recognised interest" have the right to bring proceedings to enforce national environmental laws and to seek remedies for environmental harm. In the continent of Asia, the ASEAN Agreement on the Conservation of Nature and Natural Resources 1985 contains duties for parties to involve the participation of the public in the planning and implementation of conservation measures. In the newly independent states (NIS) of the former Soviet Union there has been a willingness to embrace principles of public participation in decision making. Many of the constitutions of these new nations, grant and recognize the existence of such rights. However in many cases, although laws have been put in place to allow this, little has been done to provide the infrastructure to allow them to have a practical effect.

On the 30th October 2001 the UN/ECE Aarhus Convention ${ }^{19}$ came into force. This was a major development for procedural rights relating to the environment in the region of Europe and some of the former Soviet states of central Asia. It is the most far reaching manifestation to date of Principle 10 of the Rio Declaration. States who are party to the convention, pledge to introduce laws that provide rights of access to information, public participation in decision making and access to justice in environmental matters. Rather than having the character of a "soft law" declaration, it is likely to have a real impact as many signatory states have already begun the process of incorporating its provisions into their national law.

It is therefore in this area of procedural rights that it is possible to observe a very real fusion between international human rights law and international environmental law. In this area, it is fair to say that there has been tangible development but that the issues of sovereignty and the problem of guaranteeing environmental standards still dog the development of a substantive environmental right in the international arena.

\subsection{Human rights law in general}

Some of the major human rights treaties came about prior to the recent groundswell of concern for the environment and for this reason would not have addressed the environment directly. ${ }^{20}$ However, major human rights instruments recognise the right to

\footnotetext{
18 E.g. see James Cameron and Ruth Mackenzie, “Access to Environmental Justice and Procedural Rights in International Institutions", in Human Rights Approaches to Environmental Protection, 129 (Alan Boyle and Michael Anderson eds.) (Oxford University Press, 1996); see also (Donald Zillman, Alistair Lucas and George Rock Spring eds.), Human Rights in Natural Resource Development-Public Participation in the Sustainable Development of Mining and Energy Resources (Oxford University Press, 2002).

19 Adopted at the 4th United Nations Economic Commission for Europe [hereinafter UNECE] Ministerial Conference, Aarhus, 25 June 1998; U.N. Doc. ECE/CEP43. (1998).

${ }^{20}$ See for example the Universal Declaration of Human Rights G.A. Res. 217, U.N. GAOR, 3rd Sess.,
} 
life ${ }^{21}$ and many recognise the right to health, ${ }^{22}$ both of which can be linked to the need to protect the environment. Some human rights lawyers are reluctant to accept the notion of environmental rights per se. This is sometimes due to a fear that the adoption of new rights could have the tendency to weaken existing rights. This may occur where there is a conflict with other more traditionally accepted human rights. ${ }^{23}$

What is interesting in looking at the application of human rights to environmental issues is that of the three categories of rights, "civil and political rights", "economic, social and cultural rights" and "third generation (solidarity) rights", there is the potential for the use of all three categories. For example, "civil and political" rights could be invoked to protect the right to life or procedural rights of participation. An example of "economic, social and cultural rights" being used, may be an action brought to protect health standards owing to unwarranted levels of pollution. "third generation (solidarity) rights" could be used to protect indigenous peoples from development causing environmental degradation of their traditional lands.

\subsection{Environmental rights as part of international and regional human rights law}

Although it would appear to be appropriate that the environment be protected through the use of human rights, none of the truly major international human rights treaties have gone as far as to specifically include an environmental right as such. ${ }^{24}$ As popular concern over the dangers of environmental issues has developed since the mid to late 1960s and since some of the major international human rights treaties preceded this, ${ }^{25}$ it comes as little surprise that they do not mention the issue.

On the other hand there have been regional treaties that have included such rights. The African Charter of Human and People's Rights $1981^{26}$ states that people should have a "general satisfactory environment favourable to their development". The Additional Protocol to the American Convention on Human Rights in the Area of Economic, Social and Cultural Rights (The Protocol of San Salvador) 1989 asserts an obligation on states to "protect, preserve and improve the environment" and it grants a right of individuals to "live in a healthy environment." 27 The Declaration of Santa

Part 1, U.N. Doc. A/810 (1948) [hereinafter UNDHR]; The International Covenant on Civil and Political Rights (1966), 6 I.L.M. 368 (1967) [hereinafter ICCPR]; The International Covenant on Economic, Social and Cultural Rights (1966), 6 I.L.M. 360 (1967), [hereinafter ICESCR]; and the European Convention for the Protection of Human Rights and Fundamental Freedoms (1950), 213 U.N.T.S. 221, U.K.T.S. 71 (1953), Cmnd 8969. In force 3 September 1953. Amended by Protocol No. 11, in force 1 November 1998.

${ }^{21}$ See e.g. the UNDHR (1948) Article 3 ibid.; The Convention on the Rights of a Child (1989) Article 6, G.A.Res. 44/25, U.N. GAOR, 44th Sess., U.N. Doc. A/Res/44/25, reprinted in 28 I.L.M. 1448 (1989).

22 See e.g. the ICESCR (1966) Article 7(b) supra note 20; The Convention of the Rights of the Child (1989) Article 24 ibid.

${ }_{23}$ See Robin Churchill, "Environmental Rights in Existing Human Rights Treaties", in Human Rights Approaches to Environmental Protection, 89, 106, supra note 18.

${ }_{24}$ Although the ICESCR (1966) at Article 12(2)(b) does provide for the need to take steps for the 'improvement of all aspects of environmental and industrial hygiene.' supra note 20.

${ }_{25}$ See the UNDHR (1948), the ICCPR (1966) and the ICESCR (1966) supra note 20.

${ }^{26}$ O.A.U. Doc CAB/LEG/67/3/Rev. 5, effective October 1996, also available at 21 I.L.M. 59

2728 I.L.M. 156 (1989). Article 11 states that 'everyone shall have the right to live in a healthy environment and to have access to basic public services.' Also 'The state parties shall promote the protection, preservation and improvement of the environment.' 
Cruz 1996 states, "that human beings are entitled to a healthy and productive life in harmony with nature and as such, are the focus of sustainable development concerns." ${ }^{28}$ (This document can be seen more as a policy document rather than one which confers specific rights; its emphasis lies in strategies of sustainable development.) As far as the African Charter of Human and People's Rights is concerned, the lack of financial resources and the lack of a truly independent authority are major drawbacks for its effective implementation. ${ }^{29}$

Some more recent international human rights law treaties have included provisions relating to the environment. For example the Convention on the Rights of the Child refers to the need for education relating to the environment. ${ }^{30}$ The ILO Convention Concerning Indigenous and Tribal Peoples in Independent Countries (1989) declares that states should safeguard the rights of indigenous peoples to the natural resources of their lands and take special measures to protect and preserve their environments. ${ }^{31}$

\subsection{Existing (non-environmental) human rights that can be of use in protecting the environment}

The lack of human rights that specifically protect the environment can be seen as a lacuna in the law. However in recent years there have been interesting cases where other provisions within human rights instruments have been used as legal tools with which to protect the environment. However on examining this category of human rights it is noted that they do not adequately fulfil the function of environmental protection.

A rare example was when the Yanomami people of Brazil made a successful claim to the Inter-American Commission on Human Rights ${ }^{32}$ in relation to a highway building project through their homelands. In this particular case there were deemed to be violations of the right to life, health and food under the American Declaration of the Rights and Duties of Man. It must be said that such cases are the exception rather than the rule. It also has to be said that when these types of cases do manage to make it to a commission, they are often protracted owing to the fact that domestic remedies must be exhausted before consideration will be given. In the above case, the legal victory for the complainants neither stopped the environmental degradation that took place nor reversed it. Unfortunately there are many cases where complainants have attempted to assert human rights as a result of environmental degradation but have failed to secure redress. ${ }^{33}$ As Zarsky states,

\footnotetext{
28 O.A.S. GT/CCDSS-51/96 rev. 2 (Nov 26 1996).

29 See Nelson Enonchong, "The African Charter on Human and Peoples Rights: Effective Remedies in Domestic Law?" 46, No 2 Journal of African Law, 197 (2002).

${ }^{30}$ Convention on the Rights of a Child (1989), 29 I.L.M. 1340 (1990) Article 29, para. (e).

31 International Labour Organisation Convention (1989), 72 I.L.O. Off. Bull. 59 (1989); 28 I.L.M. 1382 (1989) [hereinafter ILO Convention]; See articles 15(1), 4(1) and 7(4) respectively.

${ }^{32}$ Case No 7615 of 5th March 1985, Ann. Rep of Inter-Am C.H.R., OAS Doc. OAE/Ser.L/V/II.66, doc.10 rev. 1, 24 (1985).

33 See for example, Powell and Rayner v. United Kingdom, 172 Eur. Ct. H.R. 5, (1990); Balmer Schafroth and Others v. Switzerland, 43 Eur. Ct. H.R. 1346 (1997); Woon Tan Kan and 7 others v. Asian Rare Earth Sdn Bhd, Civil Suit No 02-313-92; 4 C.L.J. (Malaysia) (1992).
} 
[t]he poor and marginal suffer the brunt of environmental pollution and natural resource degradation. Indeed they often suffer outright expropriation of land, forests, fisheries and other natural resources. Moreover, because the rights of the poor to have a political voice receives the least protection, they are often the least able to press for just compensation - or to just say "no" to unwanted development. ${ }^{34}$

There have been some significant developments in the jurisprudence of the European Court of Human Rights [hereinafter ECtHR] which has dealt with a number of cases of an environmental nature and shown an increased willingness to tackle the difficult problems at stake. It is worth taking special note of these as the ECtHR is probably one of the most highly developed of the regional human rights tribunals.

In the case of Lopez Ostra v. Spain (1995), ${ }^{35}$ the court held that the effect on a neighbour of severe environmental pollution (noxious fumes) amounted to a breach of Article 8 of the European Convention on Human Rights as it affected the applicant's enjoyment of "private and family life". In the case of Guerra and Others v. Italy $(1998)^{36}$ the court stated that the failure of the authorities to provide information relating to the health risks of a nearby chemical plant was also a breach of Article 8 .

The ECHR has however been reluctant to attempt to interfere with state policies and as such takes account of the arguments relating to broad public and economic interests. In the case of Greenpeace Schweiz v. Switzerland (2002), ${ }^{37}$ which concerned the operation of a nuclear power station, the Commission ruled that only applicants recognised under national law and not those less at risk or NGOs were entitled to invoke particular rights relating to the operations in question. ${ }^{38}$

More recently the case of Hatton and others v. The United Kingdom (2003) ${ }^{39}$ attracted a lot of attention. It related to the level of noise that the government should permit residents in the locality of Heathrow airport to endure. The court had the difficult task of balancing the economic interests of the UK and the airline industry against the nuisance that noise from flights causes. The case was ultimately referred to the Grand Chamber of the ECtHR, whose final judgement was given in $2003 .{ }^{40}$ It stated that there had been no breach of Article 8 , but recognised that there had been a breach of Article 13 (an individual's right to an effective remedy). It went even further to say that, "it would not be appropriate for the Court to adopt a special approach in this respect by reference to a special status of environmental human rights." 41

There are certain key observations that can be made by looking at these types of cases. Firstly, it can be seen that in the application of existing rights to protect the environment, they usually relate to particular issues concerning individuals and their enjoyment of their own specific environments. There is little evidence of these rights

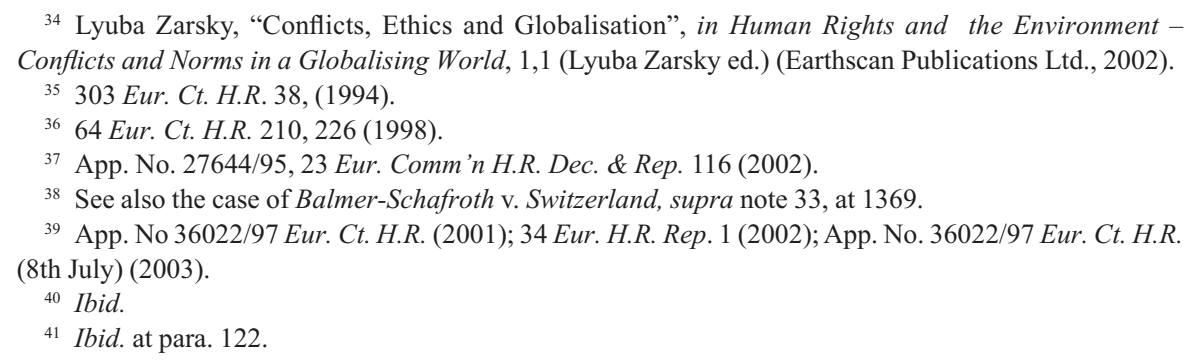


being used to protect the environment generally and therefore seem to require an association with, or an element of, direct danger or harm to humans before they become operational. ${ }^{42}$ Secondly, the institutions concerned, appear to be highly reluctant to interfere with the decision making processes of states and thus proffer governments a wide margin of appreciation in determining what is in the "public interest". There is some limited evidence to suggest that this latter trend is changing. ${ }^{43}$

Lastly in this section it should be noted that owing to the various provisions within human rights treaties, national constitutions and within environmental law treaties relating to the right to health, there are those who argue that the right to a "healthy environment' has reached the status of being regional customary international law and that it is developing as a rule of customary international law. ${ }^{44}$

\subsection{Constitutional rights}

Constitutional rights are of crucial importance. The reason for this is that they are inalienable, short of course of constitutional amendment and also they are built into a nation's legal system and thus in principle offer the potential for individuals to challenge decisions of the state in the event that those decisions are thought to be violations of the constitution.

Some constitutional provisions are regarded by their governments as being principles and as such there are no provisions within their legal systems for challenge. ${ }^{45}$ However some constitutional provisions are enshrined within a legal framework that will allow legal challenges in the event that a violation is deemed to have occurred. Therefore the justiciability varies from jurisdiction to jurisdiction and also from the types of rights within any given constitution.

As with the previous section on the application of human rights to environmental degradation, it is possible to examine two types of constitutional rights. Those that are specific rights concerned with the protection of the environment and those that were not created originally with a view to protecting the environment but which have been used to that effect. Rand McNally state that, by 1998, of the 203 recognised nations, 81 had either rights to a healthy environment in their constitutions, or a duty to defend or protect it. ${ }^{46} \mathrm{New}$ countries that have either recently gained independence or that have become democratised often adopt constitutions and often include environmental provisions. Some of the newer African nations fall into this category. Some more established nations such as Argentina have incorporated environmental rights by way of

\footnotetext{
${ }^{42}$ For example, the absence of human rights being used to pose arguments in the cases associated with the UK's new MOX plant (mixed oxide fuel) at Sellafield. See Barbara Kwiatkowska, "The Ireland v United Kingdom (Mox Plant) Case: Applying the Doctrine of Treaty Parralelism", Vol. 18, 1 The International Journal of Marine and Coastal Law, 1 (2003).

${ }^{43}$ See F.S. v. Italy App. No. 19734/92, 94 Eur. Comm'n H.R. Dec. \& Rep. 39, 53 (1998).

${ }^{44}$ For example John Lee, "The Underlying Legal Theory to support a Well Defined Human Right to a Healthy Environment”, 25 Colum. J. Envtl. L. 283, 339 (2000).

${ }^{45}$ See Steiger, Demel, Fey and Malanczuk, "The Fundamental Right to a Decent Environment", in Trends in Environmental Policy and Law, 4 (IUCN Gland. Switzerland 1980).

${ }^{46}$ Rand McNally, Millenium World Atlas of Nations, 209, 212 (1999).
} 
amendments to their existing constitutions. It should also be noted that although the US does not have an environmental right within its national constitution, certain US states do now have such a right within their own constitutions. ${ }^{47}$

Certain parts of the world have developed their constitutional rights more than others. Though South America has widespread environmental problems, it provides evidence of interesting work that has been done in developing such rights. Fabra and Arnal provide an overview. ${ }^{48}$ There are many instances where such rights have been cited effectively. For example in Argentina, an environmental right was introduced in 1994, but even prior to this the judiciary had referred to other rights in an imaginative way. In 1993 the judiciary asserted rights in a case seeking to protect fisheries and wildlife in a particular lagoon. It was stated that "[t]he right to live in a healthy environment is a fundamental attribute of people. Any aggression to the environment ends up becoming a threat to life itself and to the psychological and physical integrity of the person, which is based on ecological balance." ${ }^{49}$ The court also stated that, "a change on the environment can have an effect not only to our quality of life but also to the quality of life of our descendants. $" 50$

It is possible to examine further interesting jurisprudence of this nature that comes from environmental rights in Colombia, ${ }^{51}$ Chile, ${ }^{52}$ Peru $^{53}$ Ecuador $^{54}$ and Guatemala ${ }^{55}$ amongst others. Razzaque comments on the constitutional rights of India, Bangladesh and Pakistan in South Asia and the African countries of South Africa and Nigeria. ${ }^{56}$ The courts in India now have a reputation for their use of rights based arguments in the protection of the environment. Divan and Rosencranz state that, "few bureaucrats have effectively exercised their authority unless compelled to do so by judicial oversight."

\footnotetext{
${ }^{47}$ For example the constitutions of Montana, Illinois, Rhode Island and Pennsylvania.

48 Joint UNEP-OHCHR Expert Seminar on Human Rights and the Environment, Review of jurisprudence on human rights and the environment in Latin America, Background Paper No 6 (14-16 January 2002), available at <http://www.193.194.138.138.190/enironment/bp6.htm.>

${ }^{49}$ Margarita v. Copetro Sa Camara Civil y Comercial De La Plata. Ruling of 10.5.1993, available at $<$ http://www.eldial.com. $>$.

${ }^{50}$ Ibid.

51 Antonio Mauricio Monroy Cespedes. Sala de revision de tutelas de la Corte Constitucional. T-92/93 19.2.1993.

52 Comunidad de Chanaral v. Codeco Division el Saldor. S/ Recurso de Proteccion. Corte Suprema $28,7.88$.

53 Sociedad Peruana de Derecho Ambiental v. Direccion Regional Del Ministerio de Pesqueria. Unidad Agraria Departmental de Tumbes del Ministerio de Agricultura y Concejos Provinciales de Zarumilla y Tumbes del Ministerio de Agricultura y Concejos Provinciales de Zumilla y Tumbes. Corte Suprema de Justicia, Espediente No 1058-92. Dictamen Fiscal No 1476-92. 17.2.1993.

${ }_{54}$ Arco Iris v. Instituto Ecuatoriano de Mineria y Minesterio de Agricultura Ganaderia. Tribunal de Garnantias Constitucionales. Caso No 224/90. Resolucion No 054-93-CP.

55 Concesiones otorgadas por el Ministerio de Energia y Minas a Empresas Petroleras. Resolucion en Conciencia del Procurador de los Derechos Humanos de Guatemala en Materia Ambiental. Exp. 002-98/D.S. 10.10.98.

${ }^{56}$ Joint UNEP-OHCHR Expert Seminar on Human Rights and the Environment, Human rights and the environment: the national experience in South Asia and Africa, Background Paper No 4, (14-16 January 2002), available at $<\mathrm{http}: / / 193,194.138 .190 /$ environment/bp4.html $>$.

57 Shyam Divan and Armin Rosencranz, Environmental Law and Policy in India - Cases and Materials and Statutes 40 (Oxford University Press, 2001).
} 
The judiciary have intervened in imaginative ways, by liberalizing the traditionally restrictive view on locus standi, ${ }^{58}$ making use of class actions ${ }^{59}$ and representative standing, ${ }^{60}$ utilizing the public trust doctrine ${ }^{61}$ and developing public interest litigation generally. ${ }^{62}$ There are many cases that can be cited as examples. The case of Municipal Council Ratlam v. Vardichand and others $(1980)^{63}$ represents some fairly common issues. The sanitation within the Ratlam Municipality was extremely poor. This resulted in horrendous pollution and dangerously unhealthy living conditions. When the case was brought before the court, the council claimed that it did not have the financial resources to remedy the situation. The court responded by saying that, "financial inability, decency and dignity are non-negotiable facts of human rights and are a first charge on local self governing bodies. ${ }^{\circ 64}$

In the Philipines the much spoken of Minors Oposa case ${ }^{65}$ was brought by a number of minors in conjunction with an environmental organization. The claimants requested that the court cancel all existing Timber License Agreements. The Supreme Court upheld the arguments submitted by the claimants on the basis of the constitutional duty of the state to, "protect and promote the right to health of the people and instill health consciousness among them." ${ }^{\prime \prime 6}$ The court also based its decision on the principle of "intergenerational equity and the right to a clean environment." It has to be said that the case did not in fact result in any of the timber licensing agreements being revoked and is of interest due to its development of jurisprudence. ${ }^{67}$

In Africa there are fewer examples of this kind of law making. South Africa does have an environmental provision in its constitution however it is probably too early to state to what extent the right will really develop. However there are numerous cases where it has been used at localised levels to bring environmental issues before the courts. In the case of The Director, Mineral Development Guateng Region and Saol Mining (pty) Ltd v. SAVE the Vaal Environment and others (1999), ${ }^{68}$ the Supreme Court held that prior to a mining permit being granted, the government must be prepared to listen to the views of people concerned about issues such as the destruction of plants and animals, pollution, loss of jobs and small businesses and property values. They also stated that the government must ensure, that development meeting current needs does not compromise the needs of future generations.

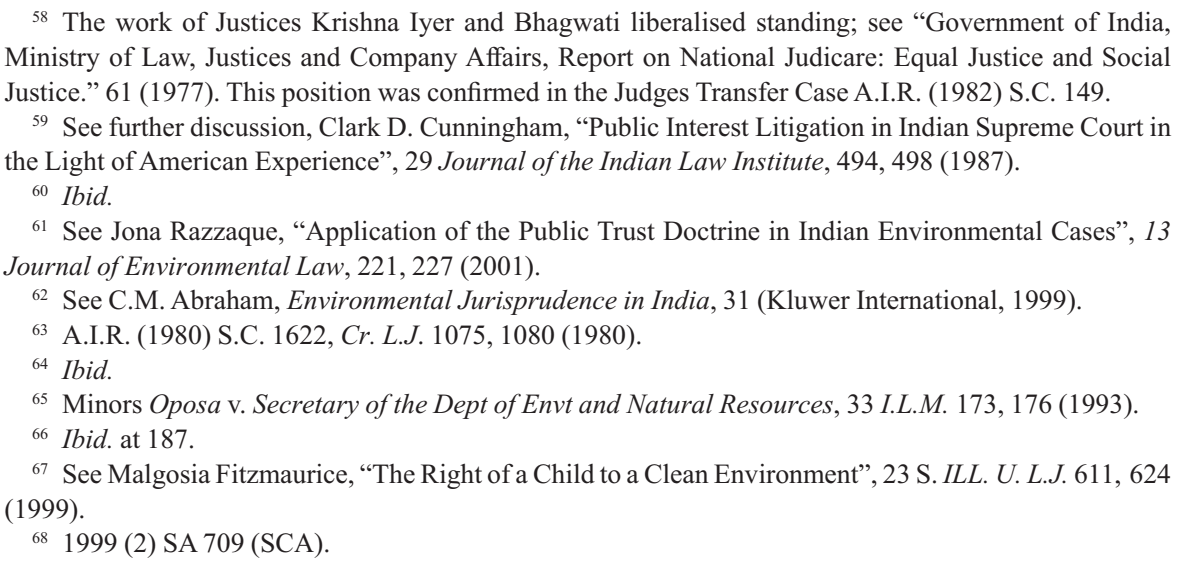


In many of these types of cases they are really only achieving what a good environmental protection agency could achieve if run properly and effectively. In some cases even where a positive judgement has been made, the problem of enforcement still remains very difficult. It is for this reason that Hans Dembowski on reviewing India's environment in terms of soil erosion, lack of sanitation, deforestation and pollution, states that, "overall India's environmental situation is bleak." 69

What also has to be noted, are the failures in constitutional rights cases, where actions have been brought to oppose major government projects. For example the Supreme Court of India upheld the building works of the highly controversial Narmada Dam project which had the effect of flooding large areas and displacing an estimated 100,000 people from their traditional homelands. ${ }^{70}$

One thing that these cases show, in spite of their varied origins, is the inalienable link between human rights and the environment. Whether stated explicitly or through direct inference the courts have often recognised man's dependence on the environment for his survival and have recognised the environment as being fundamental to the rights of life and health.

\subsection{The International Court of Justice}

There has been limited attention paid to the issue of human rights and the environment by the International Court of Justice [hereinafter ICJ]. However, in a 1997 Judgement in the Case Concerning the Gabcikovo Nagymaros Project, ${ }^{71}$ the ICJ did give regard to the fact that since the original negotiations between the two states that preceded the dispute, new international environmental norms had become established. Judge Weeramantry stated in a separate opinion that,

[t] he protection of the environment is likewise a vital part of contemporary human rights doctrine, for it is a sine qua non for numerous human rights such as the right to health and the right to life itself. It is scarcely necessary to elaborate on this, as damage to the environment can impair and undermine all the human rights spoken of in the Universal Declaration and other human rights instruments. While, therefore all peoples have the right to initiate development projects and enjoy their benefits, there is likewise a duty to ensure that those projects do not significantly damage the environment. ${ }^{72}$

He also stated that the people of Hungary and Slovakia are, "entitled to the preservation of their human right to the protection of the environment." " Such individual opinions do not have the same importance as majority judgements, but they are illustrative of the recognition at the highest judicial level of the concept of protecting the environment with human rights.

\footnotetext{
${ }^{69}$ Hans Demboswki, Taking the State to Court: Public Interest Litigation and the Public Sphere in Metropolitan India, 63 (Oxford University Press, 2001).

70 Available at $<$ http://www.narmada.org/sardarsarovar.html $>$.

${ }^{71}$ Reprinted in 37 I.L.M. 162 (1997).

72 Ibid., ICJ Judgment 25th September (1997) at 206.

${ }^{73}$ Ibid. at 204.
} 
In 1995 the ICJ heard a case brought by New Zealand relating the intention of France to carry out nuclear tests in the Pacific Ocean. ${ }^{74}$ Ultimately the ICJ refused to pass judgement as it decided that it did not have jurisdiction on the issue. However, there were three dissenting opinions who did address the issues. Judge Weeramantry ${ }^{75}$ found that there was a prima facie obligation on France to carry out an EIA and he also referred to international support for the precautionary principle and intergenerational equity. Again though the dicta in this case is not legally binding in any respect, it does reflect a growing recognition amongst some of the judiciary at the ICJ to bring new environmental principles into the reasoning of their judgements. As intergenerational equity is a central theme in the establishment of environmental rights, this is very positive.

\subsection{Overview of the existing law}

It has therefore been possible to observe that in international environmental law generally there is no generic human right to a good environment. However there are procedural rights which are commonly accepted and it is possible to argue that they have become part of customary international law in many areas.

In terms of human rights law itself, environmental rights have made little progress in this arena although there has been some use of pre-existing rights to protect people in matters which concern the environment.

There has been progress on the national level where constitutional rights have been used to protect the environment. This activity illustrates that local experts are often the ones best suited to tackle local environmental issues. Many judgements recognise the link between human rights and the environment and the necessity to protect the environment as a human right.

Certain judiciary of the international court of justice have made some useful pronouncements that would support the general movement towards the provision of a human right to a good environment.

\section{The reason for the human right to a good environment}

For hundreds of years rights have been used successfully to deal with social and political problems. ${ }^{76}$ A good example of rights being used in this way was the Magna Carta in England and Wales in 1215. ${ }^{77}$ As time has gone by, certain rights have been elevated to a higher status which are consistent with the later notion of human rights. As early as 1968, the General Assembly of the United Nations (UN) recognised that impairment

\footnotetext{
74 Advisory Opinions on the Legality of the use by a State of Nuclear Weapons in Armed Conflict, ICJ Reps. 35 I.L.M. 809 (1996).

${ }^{75}$ Ibid., dissenting opinion at page 882 .

${ }^{76}$ It must be noted that though rights have been used for centuries not all rights can be regarded as universal, natural or human rights.

77 See Chris Brown in Human Rights in Global Politics, 106 (Tim Dunne and Nicholas J. Wheeler eds.) (Cambridge University Press, 1999).
} 
of the environment could have a direct effect on a person's enjoyment of basic human rights. ${ }^{78}$ Perhaps it was for these reasons that in 1974, the Nobel Prize winner Rene Cassin expressed the opinion that human rights protection should be extended to a healthful and decent environment. ${ }^{79}$ Such opinions were not isolated; a book by W. Paul Gormley in 1976 entitled "Human Rights and Environment: The Need for International Cooperation" 80 detailed the inherent links between human rights and the environment.

In 1979 an American based Project/Council on Foreign Relations stated that, "human dependence on environmental quality is becoming so evident that it seems assured that it will begin to be treated as a dimension of human rights in the 1980s." The prophecy in this quotation did not come true. However it is indicative of the sense of urgency that was felt at that time in relation to environmental problems. The subsequent dominance of the concept of "sustainable development" may perhaps have overshadowed the need for a right to a good environment. However it can be argued that the concept of "sustainable development" has not proved to be the panacea in practice that it promised to be in theory.

\subsection{Scientific background}

Before going further with the reasoning for the establishment of a human right to protect the environment, it is necessary to discuss the scientific basis of the need. It is crucial to examine the physical, chemical and biological links that exist between human rights and the environment. The first question that must be answered in analysing the issue of the environment as a whole is, "how does life on this planet work?" Science tells us that it works by way of ecosystems. Botkin and Keller state that,

[a]n ecosystem is made up of two major parts: non living and living. The non-living part is the physicalchemical environment, including the local atmosphere, water, and mineral soil (on land) or other substrate (in water). The living part, called the ecological community, is the set of species interacting within the ecosystem. ${ }^{82}$

They then explain that,

[s] ustaining life on earth requires more than individuals or even single populations or species. Life is sustained by the interactions of many organisms functioning together, in ecosystems, interacting thorough their physical and chemical environments. Sustained life on Earth, then, is a characteristic of ecosystems, not of individual organisms or populations. ${ }^{83}$

78 The United Nations General Assembly [hereinafter UNGA] recognised the relationship in G.A. Res. 2398 (XXII), U.N. GAOR, 23rd Sess., Supp No. 18, at 3, U.N. Doc A/L.553 and Add. 1-4 (1968).

79 See R. Cassin, Introduction: "The International Law of Human Rights", IV Recueil des Cours, 144 (1974)

${ }^{80}$ Gormley, Human Rights and Environment: The Need for International Cooperation, 1 (Sijthoff, Leyden, 1976).

81 Jorge I. Dominguez, Nigel S. Rodley, Bryce Wood, Richard Falk, Enhancing Global Human Rights, 227 (1980s Project/Council on Foreign Relations - The McGraw-Hill Book Company, 1979).

82 Botkin and Keller, Environmental Science, 97 (4th Edition. John Wiley and Sons Inc, 2003).

83 Ibid. 
The scientific argument therefore is that this planet has sustained life for approximately 3.5 billion years and the, "environment at the global level must meet the same basic requirements as any local ecosystem." ${ }^{\text {84 }}$

The problem however lies in the disruption of ecosystems through the effects of man's activities. For example half of the worlds mangrove forests have been destroyed and with them the habitats and ecosystems relating to many tropical fish. These fish provide a major source of food for human populations. Modern society has created a high demand for specialised foods such as shrimps. Shrimp farming can be highly profitable in the short term but all too often the waste, antibiotics, fertilisers and pesticides that are used have a widespread effect on local ecosystems and unwittingly the shrimp farmers are destroying local mangroves along with the health of their own shrimp ponds. The United Nations Environment Program has estimated that a quarter of the destruction of mangroves can be traced back to shrimp farming. It is of little wonder that many people in these localities who are dependent on the health of these local ecosystems have staged protests against the shrimp farming. ${ }^{85}$

Scientists estimate that $10 \%$ of coral reefs have been destroyed and almost $60 \%$ are threatened by activities including coastal development, destructive fishing practices, overexploitation of resources, and marine pollution. ${ }^{86}$ They grow slowly and the reefs we see today are between 5,000 to 10,000 years old. This means that if we destroy them it will be difficult to fulfil our responsibilities under intergenerational equity for future generations. Reef fish provide about $15 \%$ of the worlds catch and are the main source of protein for many people of those regions. In total it is estimated that reefs provide humans with services through tourism, coastline protection and fish to the value of around $\$ 375$ billion per year ${ }^{87}$ Reefs are also the source of many useful chemicals and medicines. From an examination of reefs, it can be seen how their ecosystems can collapse when the intricate balance in their natural cycles is disturbed. For example off the coast of the Cook Islands in the South Pacific in the 1980s over-fishing saw the almost complete loss of parrot fish and sea urchins. Owing to the fact that both of these species feed on algae, the community of ecosystems on the reef collapsed as the reef became overgrown with the algae. ${ }^{88}$

The planet also has its own natural systems in terms of weather cycles, the absorption and dissipation of water and the natural absorption and distribution of gasses to and from the atmosphere. Of course there have been natural disasters that have been recorded back to ancient times but there is evidence that man's interference with natural systems can have catastrophic consequences. For example it has been suggested that the severe flooding of the Yangtze River in 1998 was due to the fact that $85 \%$ of its forest had been lost to harvesting and the land had been converted to agricultural uses. Due to the loss of vegetation, the run off from the storms was greatly increased. The flooding of the Yangtze caused 4,000 deaths. ${ }^{89}$

\footnotetext{
${ }^{84}$ Ibid. at 107

85 Ibid. at 2.

86 Ibid. at 11 .

87 Ibid. at 11

88 Ibid. at 11

89 Ibid. at 44
} 
Similarly in Honduras, it has been suggested that the severe deforestation of the country had the effect of exacerbating the impact of Hurricane Mitch also in 1998. People had removed $50 \%$ of the forest of Honduras. In addition, fire had caused damage to about $11,000 \mathrm{~km}^{2}$ of forest. As a result of this, when the hurricane struck, the hillsides that had lost their vegetation, were not able to absorb water as they normally would and effectively the surface soil was washed away. This meant that buildings were also washed away in the flooding. This resulted in 11,000 deaths. ${ }^{90}$

The problem of food production has brought extreme responses. Owing to man's intervention, Kazakhstan, the largest wheat producer in central asia lost one third of its cropland to soil erosion during a process of "expansion" in the 1950s. ${ }^{91}$ The large scale intensification of farming techniques by using nitrogen based chemical fertilizers and pesticides has had a detrimental effect on ecosystems as those chemicals filter into and pollute groundwater and rivers with the result that they kill other forms of wildlife and ecosystems. The 16th International Botanical Congress 1999, identified 50 dead spots in the world's coastal areas. An example is the pollution in the gulf of Mexico, which has resulted from Nitrogen and Phosphorous flowing down the Mississippi river. ${ }^{92}$

Examples can also be taken from other areas such as the problem of air pollution, the emission of greenhouse gasses and so on. What is abundantly clear is that human life is reliant on many ecosystems and natural systems that are dispersed around the globe. We require air, water, food and the use of the natural resources of the planet and therefore ecosystems are key to our survival. Thus it follows that if the human population wants to guarantee the greatest chances of survival in the future it should protect the ecosystems and natural systems of the planet as a human right.

This is the reason why it is argued that the human right should be for a "good environment" as it is clear that in a world that is interconnected through ecosystems, all aspects of the environment are important. (The other very important reason is that the word "good" is easily understood and is easily translatable into other languages, which is of paramount importance in making understanding of the right accessible on a global level.)

\subsection{Institutional recognition for the link between the environment, human rights and man's future welfare}

There has been a wealth of institutional recognition of the value of ecosystems and the need to preserve nature and natural systems. For example the World Charter for Nature states that, "mankind is a part of nature and life depends on the uninterrupted functioning of natural systems which ensure the supply of energy and nutrients." ${ }^{993}$ It

\footnotetext{
90 Ibid. at 44.

91 Nicky Chambers, Craig Simmons, and Mathis Wackernagel, Sharing Nature's Interest, 40 (Earthscan Publications Ltd, 2000).

92 The 16th International Botanical Congress 1999 - comments from Dr Lubchenco, available at $<$ http://www.ecopsych.com/zombie4>.

${ }_{93}$ G.A. Res. 37/7, U.N. GAOR, 37th Sess., Supp. No. 51, 15, at 17, U.N. Doc. A/37/L.4 and Add. 1 (1982). See also the Hague Declaration on the Environment 1989, 28 I.L.M. 1308.
} 
also stated that, "every life form is unique, warranting respect regardless of its worth to man." 94

Further similar examples can be found in the preamble of the Convention on Biological Diversity, ${ }^{95}$ the Berne Convention on the Conservation of European Wildlife and Natural Habitats ${ }^{96}$ and the 1979 Bonn Convention on the Conservation of Migratory Species of Wild Animals. ${ }^{97}$ Dinah Shelton sums up mans relationship with nature, ecosystems and natural systems by saying, "[t]he Earths biosphere is an integrated whole whose sustainability depends upon the conservation of the collection of micro-ecosystems which comprise it."'98

It therefore comes as little surprise that there has been a series of very high level aspirational pronouncements calling for the recognition of man's rights relating to the protection of the environment and his duties to protect it for future generations. Some of these have already been mentioned. For example the UNCHE declaration of 1972, ${ }^{99}$ the Hague Declaration 1989, ${ }^{100}$ the UN General Assembly Resolution 1990, ${ }^{101}$ the Rio declaration $1992^{102}$ and the Aarhus Convention $1998 .{ }^{103}$ To these can be added the Bizkaia Declaration $1999^{104}$ and the UNECE draft Charter on Environmental Rights and Obligations. ${ }^{105}$ Additionally the OECD has stated that a "decent" environment should be recognised as one of the fundamental human rights. ${ }^{106}$

\subsection{Issues relating to "sustainable development"}

It is not the purpose of this analysis to go into the many arguments that surround the concept of sustainable development; much has already been written on the subject. ${ }^{107}$ However, now in the 21st century after having waited for the concept of "sustainable development" to start working in the way that it had been hoped at the Rio conference, it is evident that there is little to bind states to pursuing policies that will bring about real "sustainability". When I say real "sustainability", I mean the kind that equates to a planet that is passed on to future generations in at least as good a condition as that in which this generation came to it.

94 Ibid. at 17.

9531 I.L.M. 822, 822 (1992).

${ }^{96}$ Convention on the Conservation of European Wildlife and Natural Habitats, Sept 19, 1979. pmbl, Europ, TS No 104

${ }_{97}$ Convention on the Conservation of Migratory Species of Wild Animals June 23 (1979), 19 I.L.M. 11.

98 See Dinah Shelton, Human Rights, "Environmental Rights and the Right to Environment", 28 Stan J. Int'l L. 103, 110 (1991).

99 Supra note 2.

100 Supra note 4.

101 Supra note 5.

102 Supra note 6.

103 Supra note 19.

104 U.N. Educational, Social, and Cultural Organization, U.N. Doc. 30C/INF. 11 (Sept 24 1999).

105 Draft Charter adopted Oct 29-31 (1990).

106 "The Organization of Economic Cooperation and Development, Responsibility and Liability of States in Relation to Transfrontier Pollution", reprinted in 13 Envtl. Pol'y \& L. 122 (1984) as quoted by Shelton supra note 98 at 125.

107 See Birnie and Boyle, International Law and the Environment, $79 \mathrm{ff}$ (Oxford University Press, 2nd Ed., 2002); also Philippe Sands, Principles of International Environmental Law supra note 8 at $48 \mathrm{ff}$. 
The United Nations Conference on Environment and Development was undoubtedly a major step forward for the environment and for the process of different countries understanding each other's problems and priorities. However, the methods of achieving "sustainable development" would have required massive investment. The international framework for achieving this goal was set out in Agenda 21. Despite being a groundbreaking document, it did not provide a means of paying for all of the work that needed to be carried out and the investment that needed to be made. For example, it was estimated at the time, that it would cost US\$3.5 billion per annum to conserve international biodiversity. Between the years of 1992-1995, the Global Environment Facility (the institution charged with handling monies raised to deal with this issue) had been allocated a mere US\$700 million. ${ }^{108}$ Therefore the lack of financial support has meant that this method of achieving "sustainability" is flawed as it is reliant on huge financial investment. It has been stated that, "[n]o strategy for sustainable development can succeed without financial backing. This is borne out by the experience of Agenda 21, which lost credibility as the gap between what was required and what was available became more apparent."109 The "human right to a good environment" seeks to deal with these practical issues.

\subsection{How the human right to a good environment can be used as the way forward}

One aspect of the human right to a good environment is that it offers the possibility of internalising the costs of "sustainable development" and thus avoiding the huge financial outlays that would have been necessary with Agenda 21. It institutes a mechanism whereby environmentally degrading activities can be taxed equitably. Thus the costs of polluting or degrading the environment can be internalised and the resultant financial resources can be utilised for programmes to either clean or restore aspects of the environment that have been degraded, or to equitably compensate those whose lives have been adversely affected. This is certainly not a new concept, but one which is naturally highly politically sensitive. ${ }^{110}$ Effectively it would be possible for a state to tax that degradation which has an effect on both a national and a transnational level. Such levies accrued from forms of degradation that have a purely national effect could be used by the state to remedy environmental problems in that country. However, monies accrued through the taxation of degradation that has a transnational effect could be paid to the Global Environmental Facility in order that they too can be used to fund environmental protection, compensation and restoration where possible.

There are other well documented benefits of adopting such an approach. ${ }^{11}$ The great

108 Effective 16th March 1995, the GEF was replenished to over US \$2 billion to last for a period of 3 years - see Charles E. Di Leva, "Environmentally Sustainable Development and the World Bank", 25 International Business Lawyer No. 3, 115 at 118 (1997).

109 Barry Dalal-Clayton and Stephen Bass, Sustainable Development Stategies, 9 (A resource booking association with The International Institute for Environment and Development, the OECD and UNDP Earthscan Publications Ltd, 2002).

110 See Environmental Law, the Economy and Sustainable Development (Richard L. Revesz, Philippe Sands and Richard B. Stewart eds.) (Cambridge University Press, 2000).

111 See Michael Anderson, "Human Rights Approaches to Environmental Protection: An Overview", in Human Rights Approaches to Environmental Protection 1, 22 supra note 18. 
advantage and it is argued necessity of providing people with a right to a good environment is that it gives their interest in the environment an equality of status to other competing human rights. The necessity for this becomes more evident as the effects of environmental damage are studied in greater detail, as illustrated in previous sections. Cranston states that a human right is, "a universal moral right which is something all men everywhere at all time ought to have, something of which no one may be deprived without a grave affront to justice something which is owing to every human being simply because he is human." 112 We have already observed how the environment is necessary for man's survival and how the planet's ecosystems and its natural systems are vital to man, therefore it follows that the environment should be protected as a human right.

This would mean that there would be a greater onus on constitutional and national courts (and indeed international courts and forums) to hear cases relating to environmental degradation and to apply the standards associated with the human right. However it would also mean that the right should be applied to regulations governing all forms of business and national life. As Fitzmaurice states the substance of a right affects its "justiciability". ${ }^{113}$ It has also been argued that being a human right gives it the status to "trump" 114 other competing rights. This, as it will be seen, is not necessarily the case as the draft human right to a good environment recognises the importance of other human rights and provides a mechanism for dealing with the conflicts that can occur between them.

The human right would essentially have the effect of redistributing burdens, by forcing those who are involved in activities that degrade the environment, to pay for the cost of that harm by way of "an equitable form of compensation". It would be a powerful tool that would allow people to challenge developments and decision making more effectively. In spite of the rhetoric by governments of their intention to pursue "sustainable development" and in spite of the swathes of multilateral and bilateral environmental agreements, ${ }^{115}$ many people are powerless to effectively challenge decision making that has an effect on their environment and that of their descendants. As a human right, it would lend itself to work through constitutional courts and regulations at a national level. It is envisaged that an established right would allow national NGOs with localised knowledge and expertise, to have a greater chance to be effective in protecting the environment.

Though it is anticipated that the most effective means to protect the environment is through the application of the right at the national level, it is important that the right is given international recognition. This is because as Desgagne points out, positive duties flow from rights ${ }^{116}$ and in the same way that internationally recognised human

112 As per Rodriguez-Rivera, "Is the Human Right to Environment Recognized Under International Law? It depends on the Source”, 12 Colo. J.Int'l Envtl. L. \& Pol'y 1, 40 (2001).

113 Malgosia Fitzmaurice, "The Right of A Child to a Clean Environment", 23 S. Ill. U. L.J. 611, 612 (1999).

114 Supra note 18 at 21.

115 Supra note 112 at 6, Rodriguez-Rivera states that there at the time of writing (2001) there were over 350 multilateral treaties, 1,000 bilateral treaties and hundreds of intergovernmental instruments.

116 Richard Desgagne, "Integrating Environmental Values into the European Convention on Human Rights”, 89 Am. J. Int'l L. 263, 272 (1995). 
rights bolster corresponding rights in national constitutions, so would such an internationally recognised human right to a good environment. Birnie and Boyle put it like this, "adequate protection of the global environment depends on the interplay of international and national measures." 117 Additionally certain issues such as the atmosphere, climate change, the sea and fisheries are international issues that require resolution through international agreement. As such the right would, by necessity, have to be operative at an international level.

One of the reasons for the establishment of this right is to provide additional support for indigenous peoples. Shelton states that, "by one estimate, 85 Brazilian indigenous groups disappeared in the first half of the twentieth century as their traditional forest lands were consumed." 118 Indegenous peoples have frequently suffered as their cultures, in many cases, do not involve property rights. This is especially true where their lifestyles have been pastoral or nomadic. In addition to this, they are often particularly vulnerable to diseases from "outsiders" for which they have no immunity. In modern times, interference with their lands has come in a variety of forms, such as road building, the dumping of toxic wastes, deforestation and appropriation of lands for oil and mineral extraction.

Falk makes another interesting point relating to indigenous peoples. He says that,

Instead of being pitied as "backward" or "primitive" such peoples are now seen as having been more successful than modern societies in enabling sustainable development over long time periods. Earlier assumptions that modernization was the only desirable path seem clearly invalid and the opportunity to learn from pre modern peoples seems sensible and relevant. ${ }^{119}$

This aspect of environmental rights, raises the question of values. Stone makes this point by saying that there was a time when slavery was accepted in many societies and similarly there was a time when in western societies women were denied the right to take up professional work. ${ }^{120}$ As society has progressed, values have changed and it is clear that over the last forty years there has been a dramatic change in the way that societies now value the environment. Accordingly it is argued that the value now placed in the environment should be protected as a human right.

The right would bring about a process that could realize intergenerational equity" and one that will put the role of "sovereignty" over natural resources into its proper perspective. Intergenerational equity has been commonly accepted as a fundamental principle governing international environmental law. The human right to a good environment achieves this by tying intergenerational equity to a fixed standard. This standard is that part of the right which states that, "[a]ny decision by a person, group of people, organisation or government that brings about or could bring about degradation of the environment is contrary to the human right to a good environment and as such

117 Supra note 107 at 267.

118 D. Ribero, "De Indios e a Civilacao" (1965), noted in Dinah Shelton, A rights-based approach to public participation and local management of natural resources, 219 available at $<\mathrm{http}$ ://www.iges.or.jp/en/fc/ phase1/3ws-26-dinah.pdf.>

119 Richard A. Falk, Human Rights Horizons 138 (Routledge, 2000).

${ }^{120}$ Christopher Stone, Should Trees Have Standing? 6-9 (Kaufmann, Inc, 1972). 
is fundamentally unlawful." ${ }^{21}$ This standard is high and has its caveats but provides a sound basis upon which intergenerational equity can be achieved.

Sovereignty, has to an extent already been discussed. Shelton has stated that the organs of the state that make decisions affecting the environment, "should be limited by substantive international environmental norms." 122 Rehman speaks of sovereignty in more general terms relating to international human rights. He explains that, "[I]nternational human rights law has challenged and jettisoned the traditional rules relating to sovereignty" 123 and later he states that, "gross violations of individual and collective rights cannot be justified on the grounds of sovereignty." 24

Establishing the right to a good environment therefore would not only grant the environment a higher legal status but would provide a useful tool for challenging national sovereignty over issues where the rights of individuals, communities or future generations had been or could be compromised.

\subsection{Issues surrounding the implementation of the human right to a good environment}

Much research on the linkages between human rights and the environment has been carried out by Fatima Ksentini. In 1990, the UN Sub-Commission on Prevention of Discrimination and Protection of Minorities, requested her to put together a report on the links between human rights and the environment. ${ }^{125}$ The final report even contained a draft set of "Principles on Human Rights and the Environment". ${ }^{26}$ The report describes the linkages between human rights and the environment, ${ }^{127}$ it showed how human rights violations could also have a detrimental effect on the environment ${ }^{128}$ and it detailed how the right to development and problems related to underdevelopment could have an impact on the environment too. ${ }^{129}$

Indeed the relationship between the environment, development and poverty is one which is dealt with in depth. The Ksentini report quotes the UNDP's report of 1993 which stated that, "in developing countries some 800 million people still do not get enough food; nearly 1 billion people -35 per cent of the adult population are still illiterate; about one third of the world's total population, or 1.3 billion people, are in absoloute poverty." 130 Therefore the human right to a good environment cannot focus on the environment solely without regard to the problems of the world's poor. There

\footnotetext{
121 Supra note 1.

122 Supra note 98 at 120.

123 Javaid Rehman, International Human Rights Law, 1 (Longman Pearson Education, 2003).

124 Ibid. at 2.

125 The UN Commission on Human Rights, Sub-Commission on Prevention of Discrimination and Protection of Minorities, Human Rights and the Environment, Final Report of the Special Rapporteur. U.N. Doc. E/CN.4/Sub. 2/1994/9 74 (6 July 1994).

${ }^{126}$ Ibid.

127 Ibid. at 42-49.

${ }_{128}$ Ibid. at 61.

129 Ibid. at 17.

$130 \mathrm{Ibid}$. at 17.
} 
has to be a straight forward mechanism, which deals with the relationship between the human right to a good environment and competing human rights. This is the reason for the section within the draft that deals with the process that should take place in the event that environmental degradation is necessary in order to "satisfy other basic human rights." 131

Some of the problems relating to the use of human rights as a means of protecting the environment have already been alluded to. It is very important to address the problems that various people have put forward as it is in addressing those problems that we deal with the relevant issues and find solutions. There is concern over the scope of an environmental right. Lee speaks of the problem of definition, ${ }^{132}$ Douglas-Scott discusses the problem of unenforceability, ${ }^{133}$ Birnie and Boyle also look at the issues of uncertainty and the proper place of human rights. ${ }^{134}$ Handl states that it is misconceived to assume that environmental protection is furthered by postulating a generic human right to the environment, in whatever form. ${ }^{135} \mathrm{He}$ states that, "its application in practice would be intrinsically problematical because of the notion's latent ambiguity, that is, indeterminacy of its contents." 136 These however are comments that predate the proposed human right to a good environment.

The problem of uncertainty relating to the human right to a good environment has been resolved by applying it to all degradation of the environment. ${ }^{137}$ In this way there is no question over whether or not the right applies, there is only a question over whether or not such degradation is warranted in order to maintain other competing human rights. It should also be noted that many second generation rights (ie economic social and cultural rights) do themselves suffer from an element of indeterminacy. It is not very difficult to justify the need to apply a human right to a good environment to all aspects of the environment and all areas of degradation, as it is clear that we have a duty to future generations to preserve the environment of the planet. ${ }^{138}$ (Many would argue that we should be improving it rather than continuing to degrade it.) The problem of unenforcablility would be dealt with by taking the issue away from human rights institutions and moving them towards the mainstream fora for the adjudication of decision making processes.

131 Supra note 1.

132 Supra note 44 at 285.

133 Sionadh Douglas-Scott, "Environmental Rights: Taking the Environment Seriously", in Understanding Human Rights, 423, 434 (Conor Gearty and Adam Tomkins eds.) (Mansell, 1996).

134 Supra note 107 at 253.

135 Gunther Handl, "Human Rights and Protection of the Environment: A Mildly 'Revisionist' View", in Human Rights Sustainable Development and Environment, 117ff. (Antonio Augusto Cancado Trindade ed.)(IIDH-BID)(1995).

136 Gunther Handl, "Human Rights and Protection of the Environment", in Economic, Social and Cultural Rights, 303, 313 (Eide, Krause and Rosas eds.) (Martinus Nijhoff Publishers, 2001).

137 Supra note 1.

138 See e.g. The Report of the World Commission on Environment and Development (the Brundtland Report) Our Common Future, 43 (1987); E. Brown Weiss, "Our Rights and Obligations to Future Generations for the Environment”, 84 Am. J. Int'l L. 198, 199 (1990); The World Heritage Convention, Article 4 (1972); CITES, Preamble (1973); Biodiversity Convention, Preamble (1992); Climate Change Convention, Art. 3(1) (1992). (References from Philippe Sands, Princples Environmental Law, supra note 8 at 256-257.) 
Handl also expresses concern about its possible application in the form of differential local standards ${ }^{139}$ inconsistent with the presumed universality of human rights. In fact this may have been a problem with the kind of environmental rights or standards proposed previously. However the proposed right to a good environment dictates by its very wording that it can be applied in different ways to equitably suit the demands of human rights in the given location and to equitably deal with the environmental degradation concerned. This therefore is one of its great strengths.

Another perceived problem is that of "redundancy". ${ }^{140}$ In other words why create a new right where there are existing rights that could perform the task equally well. The other argument is of course that other forms of legal protection exist for environmental issues and these methods are internationally accepted methods that lawyers and governments are used to. The preceding section detailed the problem that lies in these arguments. Firstly, existing (non environmental) human rights have only been applied in limited circumstances and have not always been effective in protecting the environment as a whole. Secondly, the many laws and treaties relating to the environment have often had only limited success. Therefore it is argued that it is necessary to institute a human right to:

a) deal with the issue of sovereignty

b) provide a basis for inter-generational equity

c) provide a sound legal basis for individuals and NGOs to challenge governmental/industrial decision making that will or does cause environmental degradation.

d) provide governments/industry, citizens and lawyers with a sound ethical basis upon which to make decisions relating to environmental issues taking into account competing demands and other human rights.

e) provide a mechanism whereby governments can legitimately tax polluters or those harming the environment and hence release funds to compensate and reinvest in the restoration of degraded environments (and further to provide a mechanism to ensure that the latter process takes place.)

f) provide a mechanism that allows individuals and NGOs to call their governments to account over failed implementation or performance in relation to environmental agreements.

Handl has stated that a substantive environmental human right should not be pursued as it effectively, "underestimates the difficulties in operationalizing such a normative concept. They also entail significant costs of their own and divert attention from the pursuit of more promising avenues to solving urgent environmental problems." ${ }^{141}$ However the type of right proposed can be distinguished from the types of environmental rights that have been proposed in the past in that it does take into account, in its modus operandai, the limitations on resources. It can also be argued that if it is

139 Supra note 136 at 315.

140 Supra note 136 at 316; also Birnie and Boyle supra note 107 at 258; also J.G. Merrills "Environmental Protection and Human Rights: Conceptual Aspects", in Human Rights Approaches to Environmental Protection, 25 supra note 18.

141 Supra note 136 at 327. 
integrated comprehensively into existing institutions, it would not require a new expensive international organisation for its administration.

One of the keys to this right is the simplicity of its mechanism. It provides a straight forward process that assesses:

a) Whether or not the action or proposed action causes degradation to the environment. (An environmental impact assessment would be necessary.)

b) In the event that the action does cause degradation to the environment, an assessment is made as to whether or not that degradation is warranted to protect existing basic human rights.

c) If the answer to the above is "yes" then an assessment must be made of the appropriate compensation/restoration that should be made. If this were financial compensation, it would become either nationally or internationally held, depending on the nature of the degradation.

This process can be used at all levels and would be relevant to considerations by organizations such as international lending institutions and the World Trade Organization. A human right would transcend the rules of international organisations and could be incorporated into their decision making processes.

There are also those who have advocated a much narrower version; for example a human right to a healthy environment. ${ }^{142}$ However owing to the scientific understanding of ecosystems and natural processes and man's dependence upon them, the draft human right to a good environment acknowledges the worth of nature ${ }^{143}$ and the necessity to preserve it for present and future generations. ${ }^{144}$ It does not go as far as to afford natural objects rights per se..$^{145}$

One of the main problems that face human rights in general, not just environmental rights, is the level to which they are accepted by different cultures and societies. For example, China as a nation does not have the same attitude towards rights that western societies may have. In fact it has been argued that rights talk is alien to Chinese culture. ${ }^{146}$ However in a rapidly changing world we are now seeing how China is struggling to face up to environmental problems of its own and as such the human right to a good environment could work to their advantage. For example, Changhua $\mathrm{Wu}$ and Simon Wang describe the problems of the dumping of toxic waste from the US in China. ${ }^{147}$ Not only could the human right to a good environment be used effectively

142 See for example John Lee supra note 44.

143 See the World Heritage Convention (1972); The Berne Convention on the Conservation of European Wildlife and Habitat (1979); The Convention on International Trade in Endangered Species (1973); The Biological Diversity Convention (1992); The World Charter for Nature (1982); The Antarctic Treaty (1959) and the Protocol on Environmental Protection (1991); The Convention on the Conservation of Antarctic Living Resources (1980).

144 Supra note 1.

145 See supra note 120.

146 Tim Dunne and Nicholas J. Wheeler, "Introduction: human rights and the fifty years' crisis", in Human Rights in Global Politics, 1, 13 (Tim Dunne and Nicholas J. Wheeler eds.) (Cambridge University Press, 2001).

${ }^{147}$ Changhua Wu and Simon Wang, "Environment, Development and Human Rights in China: A Case Study of Foreign Wasted Dumping" in Human Rights and the Environment - Conflicting Norms in Globalising World, supra note 34 at 198. 
under such circumstances but the fact that, as a right, it is inextricably linked to other human rights, it could have the effect of broadening China's acceptance of other human rights too.

In spite of global differences in cultures and legal systems, one thing is certain and that is that man is dependent on the environment. Additionally, degradation of the environment in one country can affect the environment, ecosystems and natural systems of other countries. Therefore it is of the utmost importance that internationally recognised standards are developed and that these are then further developed into positive law.

\section{Conclusion}

In 1994, the Secretary General of the United Nations said that, "without protection of the environment, the basis of human survival will be eroded." 148 Time has shown that the principles of "sustainable development" alone will not be sufficient to protect the environment. Time has shown that the interest that present and future generations have in the environment needs to be rooted in positive law. The argument is that the human right to a good environment provides a cost effective, forward thinking and practical method of dealing with environmental problems. The first step in its introduction would be for the right to be recognised formally on an international level. The second step would be the introduction of the use of appropriate legal mechanisms and regulations that govern decision making on a day to day basis.

Further work will illustrate how the right should be applied and how it would work in practice.

${ }^{148}$ Supra note 125 at 62. 
